\title{
VIRAL MARKETING IN THE INTERNET. CHARACTERISTICS OF AN EFFECTIVE VIRUS.
}

\author{
Joanna A. Kwiatkowskal
}

ABSTRACT: Among internet users surveyed, $63 \%$ declares a negative attitude towards advertisements placed in the Internet [3]. At the same time, the value of advertising market in the Internet in Poland has a colossal potential. The internet advertisement will appeal to Internauts if the form of its content is amusing (50 percent), creative and surprising (45 percent) or when it provides consumers with useful information (34 percent) [3]. What is more, it is possible that users interact with an advertisement and pass it farther. It means that they express 'subconscious acceptance' of advertisement. Such a behaviour is known as viral marketing.

Key words: marketing, viral marketing, Internet, Viral Spoof

JEL codes: M31

\section{Introduction: The Internet era and its potential}

Internet - formerly a niche and exclusive medium, today constitutes an inseparable element of our reality. What is more, its range grows continuously. Already 49 percent of the Poles above fifteen years old declare the use of the net boon, what in terms of the population gives 14759449 of the Internauts (February-April 2009) [1].

Additionally, it is worthwhile to notice that 74 percent of people from that group use the Internet every day (Fig. no. 1) [1]. In comparison to 2007 April, this activity equalled $60 \%$ [2].

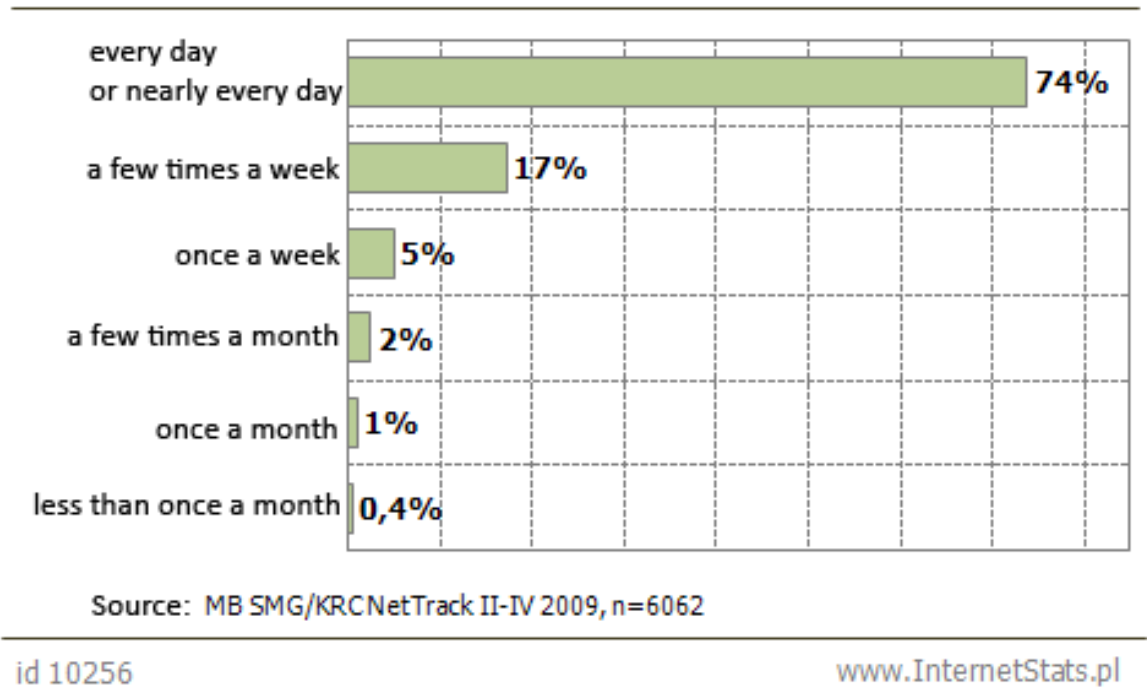

Fig. no. 1 - How often do the Poles use the Internet?

\footnotetext{
${ }^{1}$ Czestochowa University of Technology, e-mail: joanna@zim.pcz.pl
} 
Many companies that noticed the potential hidden in the above-cited numerical data, decided to use the Internet in their marketing activities.

Unfortunately, according to the newest report: The Internauts attitude to advertisements elaborated by Gemius research institution, among internet users surveyed, right up to $63 \%$ declares a negative attitude towards advertisements placed in the Internet [3]. Users are irritated the most by the advertisement form which hides the part of interesting information. Nevertheless, the internet advertisement might appeal to Internauts if the form of its content is amusing (50 percent), creative and surprising (45 percent) or when it provides consumers with useful information (34 percent) [3]. What is more, it is possible that users interact with an advertisement and pass it farther. According to the report concerning the value of the advertising market in Poland elaborated by CR Media Consulting company it is noticeable, that such behaviours are extremely desirable by marketers (Fig. no. 2) [4]. Viral marketing is a definition of such behaviours.

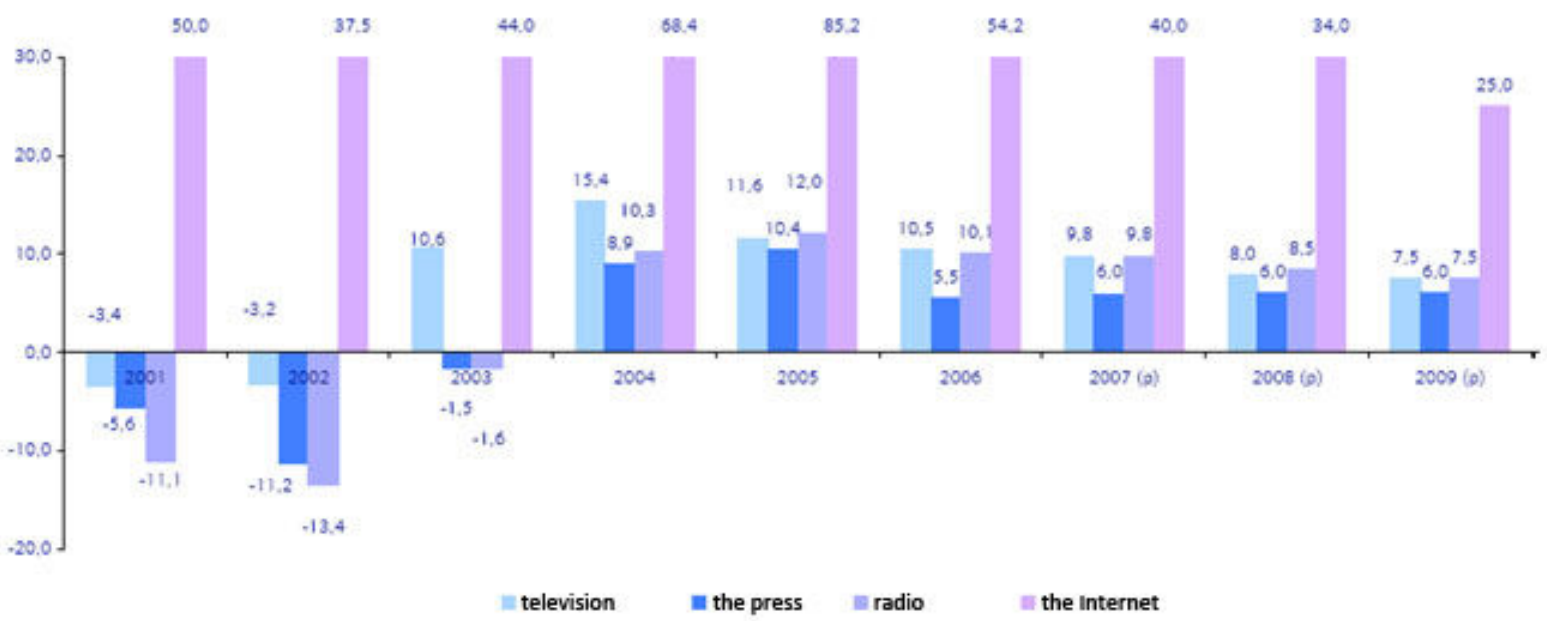

Fig. no. 2 - The dynamics of advertising market value in Poland

\section{Speaking is cheap, silence kills [8]}

The spread of information in the Internet, like biological viruses, has a exponential character (Fig. no. 3).

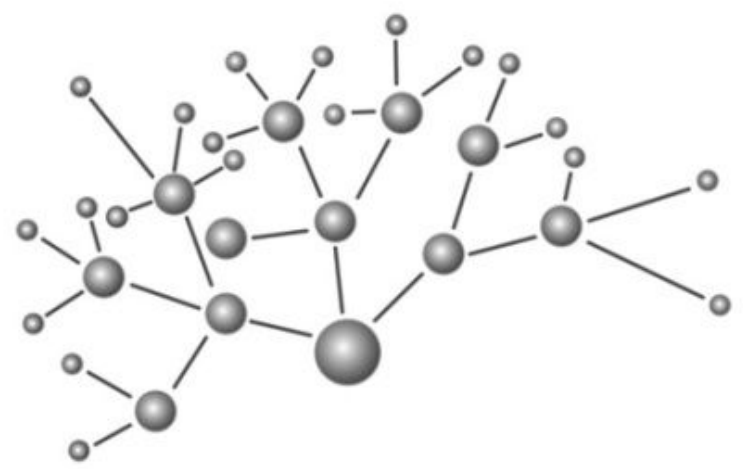

Fig. no. 3 - The exponential spread of information in the Internet Source: Pankiewicz K., E-marketing w akcji, Helion, Gliwice, 2009, p.68

Every amusing film, parody of existing advertising message or incident, etc. constitutes a potential virus (viral advertisement) (in the Latin virus means toxin or poison). The virus develops 
in three stages: infection (acceptance of the information), development (familiarization with the information) and spread (the information is passed to other users - seeding).

The track concerning the first use of viral marketing term directs to the two people connected with the Harvard Business School: Tim Drapner - the graduate of that School and Jeffrey Rayport - its lecturer [10].

Nowadays, viral marketing is included in the group of techniques called Word of Mouth Marketing (WOMM) (Fig. no 4).

\title{
Referral Programs
}

\section{Viral Marketing}

\section{Brand Blogging}

\section{Evangelist Marketing}

\author{
Community Marketing
}

\author{
Product Seeding
}

\section{Buzz Marketing}

Fig. no. 4 - Word of Mouth Marketing includes Viral Marketing

Source: Janmedia company presentation (www.janmedia.pl)

Applying different virus distribution channels:

a) the Internet communicators,

b) e-mail,

c) chats,

d) blogs,

e) mailing lists,

f) video services, etc.

marketers try to make a noise about the definite product, thus they try to increase the brand awareness.

The idea of viral marketing consists in defining group of people with high Social Networking Potential (SNP). In the second step, this group gets viral materials prepared earlier. If consumers of that information (SNP group) become infected and the receipt of the viral message is positive, there is a high probability that the virus will be passed farther to the group from outside the SNP environment. Such a behaviour means that the group express 'subconscious acceptance' of advertisement (this effect was described by Pete Brown, founder of Bore me service)[6]. In this case, a decision to open a message is aware (it equals to agreement to watch an advertisement). What is more, the attitude of a person who is watching this ad is positive.

\section{Different categories of viruses:}

In relation to the way of distribution and the form of advertising message included, we can divide viruses according to the following categories:

1) promotional virus

a) I often use tutorials that are placed on the Internet (so called Tips \& Tricks). For example, hotheads of Photoshop (programme marked by Adobe) popularize their works on the Internet. They show how to get the effects that will be similar to the ones obtained by them step by step (it might be a film or detailed description). The authors of such 
presentations are not aware that at the same time they create a promotional virus - when they pass to others useful information, they advertise a specific product (for example http://www.psdtop.com/blog/photo-effects/typographic-portrait-like-grammys-posters/).

b) we can find more and more advertising slogans in the colloquial speech. Although their everyday use does not appear in the advertising context, the associations are strong. This causes the brand, product or service awareness increasement and its strengthening (for example I'm Lovin'it, Wassssuuuuupppp?, Just do it).

c) placing advertising videos in the services such as YouTube.com

d) creation of advertising serials (for example SIMPLUS productions)

2) virus concerning product

a) specific product abilities presentation; for example cars or computer devices testes published in the Internet

b) creation of community internet services which gather fans of specific products, serials or places (for example Dr House website http://www.house-md.pl/ or service created by people who are using Ipods marketed by Apple http://www.ipodtouchfans.com/)

3) distributive virus

a) more and more companies are looking for new advertisement distribution channels for its products. Some solutions are quite innovative. When we punch Ipod enquiry into Google search engine, the first result is a description of that product in the Wikipedia (http://pl.wikipedia.org/wiki/IPod).

b) recommend to your friend function placed in many websites and services is a very popular solution

c) a very interesting solution has been introduced by the Polish Internet shop: www.merlin.pl. People who do not like surprises can use the wish list function available in this shop. This function enables to create the list of dreamed-of presents. The author of the list sends it to his/her potential benefactors.

4) virus concerning service [5]

a) the Internet forums and blogs - the Internauts discuss about definite products, brands and services

b) Google Maps advertisement - the possibility of the cost free map placement on the own webpage (the location that we are interested in is pointed)

c) the possibility of downloading popular widgets (for example Facebooker, Orange). These applications are installed on computer desktops.

How to measure the effectiveness of viral marketing?

1. CTR parameter (Cost Through Rate). It is a percentage of clicks on the advertisement in the relation to general display (formula 1 ).

$$
C T R=(\text { number of clicks } / \text { general display }) 100 \%
$$

The following chart (Fig. no 5) presents the CTR parameter values for the Kocham Cie advertising campaign produced by Immersum Agency. The advertisement was distributed via two channels. In the first case, the banner campaign was tested, in the second - the form of viral marketing. 


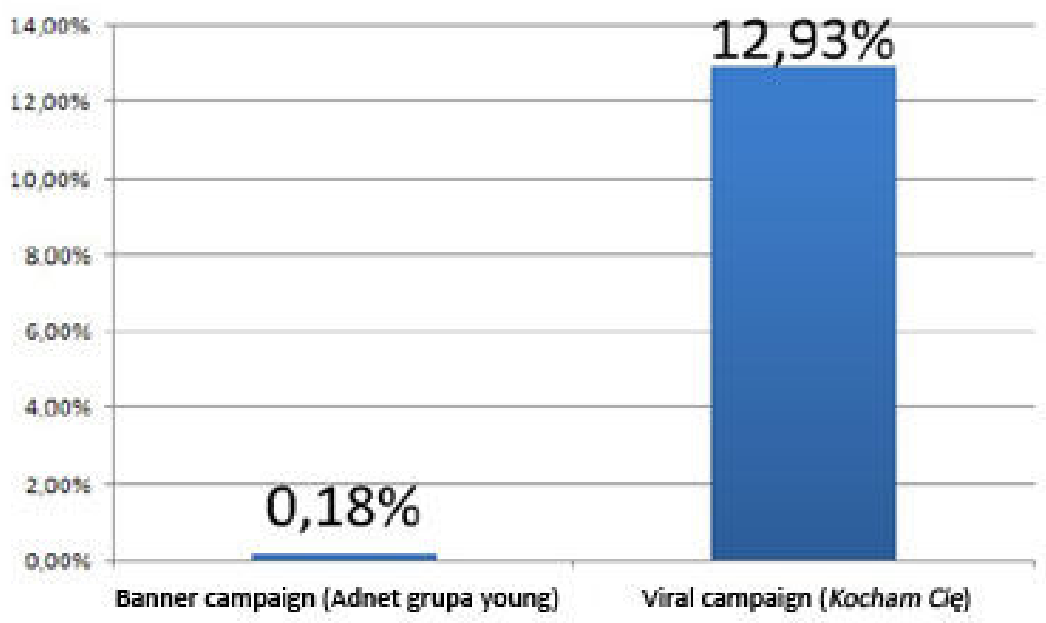

Fig. no. 5 - The percentage of people who visited the client's website after seeing the advertisement

Source: Raport Immersum Viral vs Baner, available on-line at http://www.immersum.pl/

2. ROI parameter (Return of Investment) - the return of incurred costs.

In the case of viral marketing, we can define the investment as a placement of the viral message on the Internet; the return is a number of products sold in the specific time. The influence of other factors that distort the results is the disadvantage of that parameter (for example parallel advertising campaign of this product in television).

According to Immersum Agency, in the case of viral campaign the ROI parameter is 70 times greater in comparison to banner campaign [11].

3. Estimation of the viral campaign range (evaluation of information concerning product, brand or service spread)

D. Watts and J. Peretti [9] elaborated the formula that defines the viral campaign range. They applied methodology similar to models present in epidemiology while predicting the spread of an epidemic. (formula 2):

$$
n={ }^{p N} /(1-R)
$$

- the viral campaign range

- the probability of positive reaction to campaign (product, brand, service)

- the number of people who take part in the campaign and belong to the 0 generation.

The 0 generation might be identified with a target group. People from target group belong to the proper social class, etc. and they possess features defined by marketers. 0 generation interacts with 1 generation.

- the rate of reproduction (number of people informed about product, brand or service by one person).

4. There are companies (for example DMC Agency [6]) that decides to elaborate their own spying programmes integral to viral messages. Thanks to such plugs it is possible to monitor the number of clicks or virus launches. Unfortunately, such methodology is mistaken, because it does not reflect the real effects of viral campaign gained by the brand. If, for example the viral campaign of product X was seen by 2 million people but, unfortunately, this product was bought only by 300 people, this campaign is recognized as failure. 
5. Another way to measure the effectiveness of viral marketing is the analysis of keywords punched into search engines, descriptions, comments and other content that appears in the context of specific viral campaign.

In the case of such approach, a certain matter of argument is present. Namely, if the examples of definite viral campaigns (Dove, Hotmail) placed in texts concerning viral campaigns still constitute elements of marketing activities or not?

6. Cost per click parameter (CPC) - cost of a single visit at client website.

Advertiser pays search engines for every click that leads to Internaut visit at advertiser website.

The following chart (Fig. no 6) presents the CPC parameter values for the Kocham Cie advertising campaign produced by Immersum Agency. The advertisement was distributed via two channels. In the first case, the banner campaign was tested, in the second - the form of viral marketing.

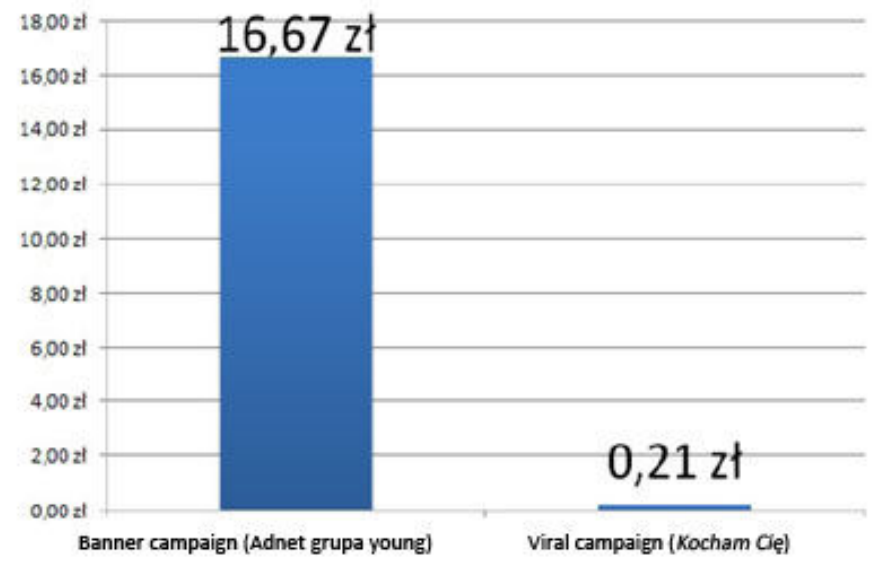

Fig. no. 6 -The cost of one visit on client's website

Source: Raport Immersum Viral vs Baner, available on-line at http://www.immersum.pl/

\section{Viral Spoof}

Viral Spoof - the valid rule in viral marketing. It runs that every viral message can be modified and parodied regardless of positive or negative impact of updated message.

The following images (Fig. no. 7) present the examples of leading Just do it slogan application (marketed by Nike) according to Viral Spoof principles.

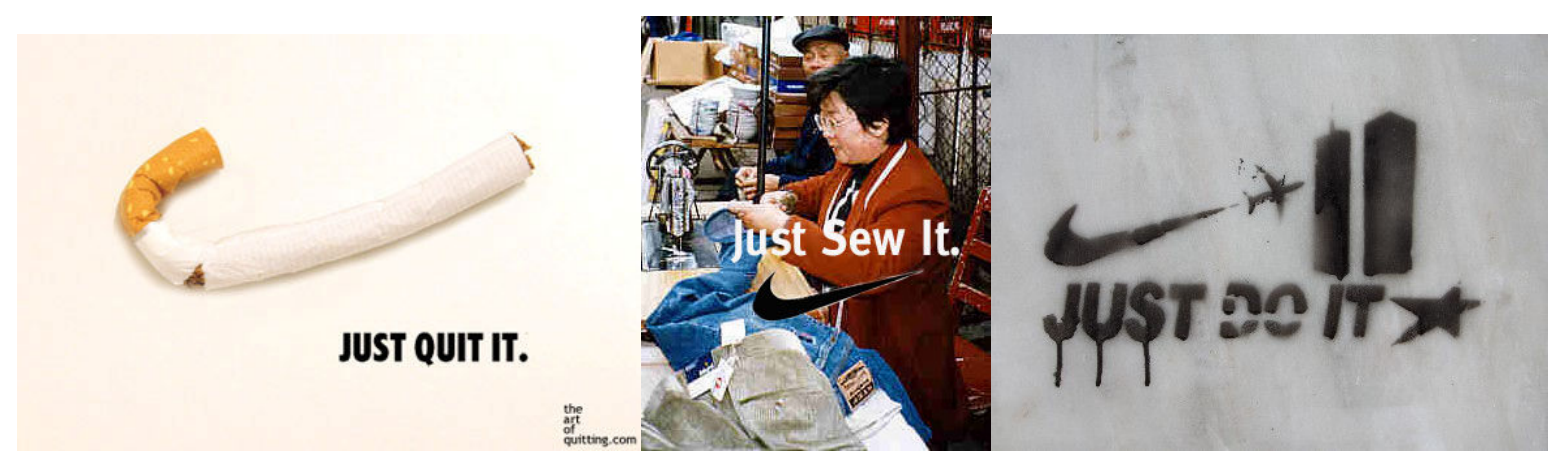

Fig. no. 7-Examples of Viral Spoof

Source:

a) http://www.stylmiasta.pl/wp-content/uploads/2007/02/justquitit.jpg 
b) http://thediscerningbrute.com/2008/02/02/\%C2\%A9-just-screw-it/

c) http://media8.mojageneracja.pl/oioooeurww/mediumk13nlk5548310b38b2d5173268.jpg

\section{Research methodology}

On the basis of existing viral messages available on the Internet the following model that characterises efficient viral campaign has been elaborated:

a) time and wave

Many viral campaigns base its assumption on so called wave. On the basis of real events (scandal, tragedy, etc.) the advertising message which constitutes the lifeblood of the whole viral campaign, is created.

Medialider.pl - little-known Polish Internet shop, took advantage of the President Lech Kaczynski speech concerning Internauts in its advertising campaign: I am not the enthusiast that a young man sitting in front of the computer, while watching films, pornography and drinking beer directly form the bottle, is voting when he feels like doing this.

The punchline of advertising film created in this way says, that apart from activities mentioned by the President, the Internauts do the shopping. In the YouTube.com service this advertisement has been watched 165642 times (data form 2009 September)

b) emotions, original idea, stereotype breaking

The virus must attract, horrify, amuse or abuse controversies.

c) this is not an ad!

Hidden (viral) advertising messages are more and more popular. A book containing recipes for cakes and published by margarine producer is a very good example. Obviously, this margarine is a obligatory ingredient of all recipes for cakes. The producer intention is to induce a reader to propagate the name of product and advertising company present in recipes[13].

d) serial

Among viral campaigns, the advertising messages which have continuity (episodes) are very popular. Will it blend? campaign concerning kitchen devices marketed by Blendect, is a very good example. The consecutive spots present how blender manages with milling different products (for example Ipod http://www.willitblend.com/).

e) The less, the better (size)

The small size of the viral messages guarantees proper access and ease of spread.

f) community - virus stimulation

Marketers can raise viral campaigns efficiency placing comments upon their viral messages on the Internet forums, blogs or community internet services. Such approach can encourage other users to familiarize with the material. It is essential to apply such behaviours competently, because the Internauts can recognize this action as manipulation, what might have negative impact on the whole campaign.

g) Free hand = Viral Spoof

It is impossible to forbid Internauts to modify viral matters

\section{Conclusions}

1) Advantages and disadvantages of viral marketing

Table no. 1

\section{Advantages and disadvantages of viral marketing}

\begin{tabular}{ll}
\hline \multicolumn{1}{c}{ Advantages } & \multicolumn{1}{c}{ Disadvantages } \\
\hline $\begin{array}{l}\text { Low cost of reaching the client } \\
\text { The virus spread is free of charge }\end{array}$ & The virus spread is uncontrolled \\
$\begin{array}{l}\text { To create an effective virus, professional tools are not } \\
\text { obligatory (for example, some advertising messages were } \\
\text { created using amateur camera) }\end{array}$ & $\begin{array}{l}\text { The virus created by us can be modified (mutation), what } \\
\text { can lead to deformation of intentional message }\end{array}$ \\
\hline
\end{tabular}


It is possible to attain high level of trust, value, position and brand knowledge

Viral marketing is more effective than traditional form of

advertising message

There is a chance to reach the consumers immune to

traditional advertising messages
There is a probability to create a negative brand image (viral marketing is defined as a double-edged sword)

The virus existence in the Internet is of unlimited duration False start - the lack of interest in virus resulting from its wrong distribution

It is impossible to measure the virus existence in the Internet

Internauts take control over the brand image and play with that image

The lack of legislative regulations concerning viral marketing

Source: own elaboration

2) The consequences of unconsidered strategy

In the case of viral campaign failure it is vital to remember, that the power of negative opinion is crushing. It has been proven many times that one unsatisfied client is able to deliver his unfavourable opinion concerning brand to other 9 people [7].

\section{References}

1. Badania Net Track firmy Milward Brown SMG/KRC, available on-line at http://www.internetstats.pl/index.php/2009/07/staz-czestosc-i-miejsce-korzystania-z-internetunettrack-iv-2009/.

2. Kazanowski, D., 2007. Nowy marketing w internecie, Difin, Warszawa, p10.

3. Internet bez reklam jest dla nas wart 2 zł, 28/08/2009, Badanie przeprowadzono w czerwcu 2009 roku. Do analizy włączono 1000 wypełnionych do końca kwestionariuszy, zebranych od internautów w wieku $\quad 15$ lat $i$ więcej, available on-line at http://di.com.pl/news/28335,0,Internet_bez_reklam_jest_dla_nas_wart_2_zl.html\#utm_source=new s_wp\&utm_medium=link\&utm_campaign=-warto-przeczytac.

4. Rynek reklamowy ${ }^{-} \mathrm{w}$ Polsce. Prognoza 2007-2009 available on-line at www.egospodarka.pl/pliki/Rynek_reklamy_ogolem_IVQ2006.pdf.

5. Michalak P.R., 2009. Daszkiewicz D., Musz A., Marketing wirusowy w Internecie, Helion, Gliwice.

6. Marketing wirusowy, E-Biznes, Multimedia, 24 kwietnia 2007 available on-line at http://www.magazyninternet.pl/artykul/280,1,marketing_wirusowy.html.

7. Ennew Ch., Banerjee A., Li D., 2000. Managing Word of mouth communication: empirical evidence,International Journal of Bank Marketing, 18/2 p.75-83

8. Levine R., Searls D., Locke Ch., Weinberger D., 2000. Manifest www.cluetrain.com. Koniec ery tradycyjnego biznesu, WIG Press, Warszawa.

9. Watts D., Peretti J., 2007. Viral marketing for the Real Word, Harvard Business Review, p. 22.

10. Viral Marketing, Wikipedia, available on-line at http://en.wikipedia.org/wiki/Viral_marketing.

11. Raport Immersum Viral vs Baner, available on-line at http://www.immersum.pl/.

12. Marketing wirusowy, Wikipedia, available on-line at http://pl.wikipedia.org/wiki/Marketing_wirusowy. 